\title{
COMMUNICATION CHANNELS THROUGH THE STUDY AND THEIR DEVELOPMENT TRENDS
}

\author{
[Komunikační kanály v průběhu studia a jejich vývojové trendy] \\ Renáta Máchová ${ }^{1}$, Martin Lněnička ${ }^{2}$ \\ ${ }^{1}$ Univerzita Pardubice, Fakulta ekonomicko-správní, Studentská 84, 53210 Pardubice \\ Email:renata.machova@upce.cz \\ ${ }^{2}$ OA a SOŠ CR Choceň, T. G. Masaryka 1000, 56536 Choceň \\ Email:martin.Inenicka@gmail.com
}

\begin{abstract}
With the continuously evolving communication technologies followed by improvements in the educational process, this paper aims to identify the development trends of communication channels and tools used by students during their study. For this purpose, a longitudinal study was designed and the surveys were carried out in 2013, 2015 and 2017. The main contribution lies in the description and identification of trends, including the recommendations on improving the quality and efficiency of the educational process regarding the choice of suitable communication channel. The results showed that the trends are represented by the increasing importance of social networks and the demand to integrate multiple communication channels into one service. The necessity to provide more educational resources through mobile applications was also found, especially in the context of learning management systems.
\end{abstract}

Keywords: communication channels, development trends, education, longitudinal study, survey.

JEL classification: C83, I21, L86

Doručeno redakci: 29.1.2018; Recenzováno: 14.2.2018; 1.3.2018; Schváleno k publikování: 14.3.2018

\section{Úvod}

Podle Devito (2008) je komunikační kanál „médium, kterým se přenášejí sdělení mezi vysílačem a př́jemcem v podobě zakódované informace. “Existují různé druhy kanálů, jako jsou hlasové, zrakové, čichové nebo hmatové. V dnešní době ale převažuje elektronická komunikace, která sice pracuje se stejnými typy komunikací jako osobní komunikace, ale už k tomu využívá jiných komunikačních prostředků, tzn. počítačových sítí, at' už drátových nebo bezdrátových.

Výměna dat a informací mezi jednotlivými aktéry vzdělávacího procesu představuje důležitý komunikační kanál, který může výrazně ovlivnit kvalitu celého procesu. S rozvojem nových Informačních a komunikačních technologií (ICT) a zároveň implementací inovovaných metod vzdělávání je nutné sledovat tento vývoj a trendy určující podoby komunikačních kanálů. To je důležité i proto, že v těchto kanálech dochází k různé úrovni šumu, často zde chybí relevantní zpětná vazba a informace je pak znehodnocena. Studenti navíc využívají ke komunikaci různé uzavřené skupiny na sociálních sítích nebo diskuzních fórech, kde má vyučující jen minimální možnosti korigovat informace, zejména pak ty, které souvisí se studijními materiály a obecně problémy se studiem (Lněnička a Máchová 2013; Máchová a Lněnička 2015).

Dále je nutné vzít v úvahu také to, že díky dostupnosti ICT je dnes většina vzdělávacích aktivit přesouvána do prostředí Internetu. Vzdělávací instituce $\mathrm{z}$ tohoto důvodu stále více využívají možností e-learningu a také komplexních systémů pro podporu výuky (Learning Management System, LMS). Využívání jednotlivých funkcí LMS, které podporují komunikaci a výměnu informací, je však často podceňováno, resp. nesprávně využíváno vzhledem k požadavkům na systém i na organizaci a fungování studijního procesu (Arkorful a Abaidoo 2015). 
Tento příspěvek se tedy zabývá analýzou různých komunikačních médií a kanálů, které studenti využívají během svého studia na vysoké škole. Cílem je identifikace vývojových trendů v této oblasti založená na statistické analýze dat z dotazníkových šetření provedených v letech 2013, 2015 a 2017. Zjištění těchto informací je důležité zejména proto, že mohou výrazně zefektivnit vzdělávací proces s ohledem na rychlost, kvalitu a spolehlivost předávané informace a zároveň vymezit nejvhodnější komunikační kanál pro daný účel, stejně jako mohou přispět k dalšímu rozvoji těchto kanálů.

\section{Metodika výzkumu a hypotézy}

Longitudinální výzkum je charakterizován tím, že zkoumá určitý jev nebo vzorek populace po určité časové období. Tento typ výzkumu je používán za účelem sledování vývojových změn. Vzdělávání tak patří k nejčastějším oblastem, kde je tento výzkum aplikován, protože umožňuje zachytit vliv získávaných znalostí a jejich dopady na rozhodovací procesy subjektů (Creswell 2012). Metodický postup tohoto příspěvku je definován tímto typem výzkumu, když se jedná o prospektivní studii, při které jsou data o vybrané kohortě (společným znakem kohorty je zde ročník studia na vysoké škole) sbírána průběžně. Tato studie tak zkoumá, jaký vliv má ročník studia na vysoké škole na výstup v podobě používání vybraných komunikačních kanálů v čase.

Za tímto účelem byla v letech 2013, 2015 a 2017 provedena dotazníková šetření, když vždy byl použit stejný dotazník, aby byla zajištěna konzistentnost výsledků. Dotazováni byli studenti prezenčního studia na Fakultě ekonomicko-správní (FES) Univerzity Pardubice, když výsledky prvního šetření byly prezentovány ve Lněnička a Máchová (2013). Porovnání vývoje mezi roky 2013 a 2015 pak bylo stručně představeno v Máchová a Lněnička (2015), nicméně bez hlubší statistické analýzy a širší diskuze výsledků.

Vlastní výzkum byl realizován formou anonymních dotazníků, jež byly rozdány mezi studenty 1., 3. a 5. ročníku. Tento výběr byl zvolen $\mathrm{z}$ toho důvodu, že studenti vyšších ročníků hodnotili změny ve využívání různých forem komunikačních médií a kanálů ve svém prvním roce a poté v aktuálním roce studia. Takto lze pracovat s větším rozpětím u zkušeností mezi dotazovanými studenty, které jsou klíčové pro identifikaci vývojových trendů. Na základě těchto skutečností byly definovány následující hypotézy:

H1: lze předpokládat, že studenti budou preferovat online komunikační kanály, tzn., že je zde patrný odklon od klasických forem komunikace a získávání informací, a to i skrze LMS a další systémy pro podporu výuky.

H2: lze předpokládat, že elektronická komunikace mezi studenty v průběhu sledovaných let studia prošla vývojem od studentských portálů směrem k sociálním sítím.

H3: lze předpokládat, že preferované kanály studentů nižších ročníků se budou lišit od těch, které používají studenti vyšších ročníků.

H4: lze předpokládat, že studenti uvítají vyšší míru integrace kurzů v LMS se sociálními sítěmi nebo dalšími službami jako je Google nebo Windows Live.

Získaná data byla následně zpracována a vyhodnocena v programu MS Excel. Za tímto účelem byla pro každý rok vytvořena datová matice, se kterou bylo dále pracováno. První krok spočíval ve výpočtu popisných statistik a jejich porovnání, když pro přehlednost jsou dále uváděny jen hodnoty průměru (Mean, M) a směrodatné odchylky (Standard Deviation, SD). Následovalo vytvoření grafů s procentuálním podílem jednotlivých odpovědí a na závěr pak bylo provedeno statistické testování hypotéz pomocí metod vhodných pro daný typ dat. 


\section{Získané výsledky a jejich interpretace}

V rámci všech sérií dotazníkových šetření bylo získáno 296 vyplněných dotazníků. Struktura studentů $\mathrm{v}$ jednotlivých letech je zachycena $\mathrm{v}$ tabulce 1.

Tabulka 1: Přehled struktury dotazovaných studentů v jednotlivých letech

\begin{tabular}{|c|c|c|c|c|c|}
\hline & $\mathbf{2 0 1 3}$ & $\mathbf{2 0 1 5}$ & $\mathbf{2 0 1 7}$ & M & SD \\
\hline 1. ročník & 23 & 51 & 39 & 38 & 11,5 \\
\hline 3. ročník & 28 & 55 & 16 & 33 & 16,3 \\
\hline 5. ročník & 21 & 35 & 28 & 28 & 5,7 \\
\hline Celkem & 72 & 141 & 83 & 99 & 30,3 \\
\hline
\end{tabular}

Zdroj: Vlastní zpracování

První otázka dotazníku se věnovala tomu, kde studenti získávají materiály a informace potřebné pro studium. Cílem této otázky bylo zjistit přesah i mimo oblast elektronických komunikačních médií jako primárních komunikačních kanálů a zdrojů informací. Studenti se zde mohli volně vyjádřit a uvést i několik odpovědí. Výsledky jsou zachyceny v tabulce 2.

Tabulka 2: Využívání vybraných způsobů komunikace a získávání informací mezi studenty a vývoj jejich procentuálního podílu v čase

\begin{tabular}{|c|c|c|c|c|c|c|c|c|c|}
\hline \multirow{2}{*}{$\begin{array}{c}\text { Rok a ročník studia / } \\
\text { komunikační kanál }\end{array}$} & \multicolumn{3}{|c|}{$\mathbf{2 0 1 3}$} & \multicolumn{3}{|c|}{$\mathbf{2 0 1 5}$} & \multicolumn{3}{c|}{$\mathbf{2 0 1 7}$} \\
\cline { 2 - 11 } & $\begin{array}{c}\mathbf{1 . ~ r o c ̌ . ~} \\
{[\%]}\end{array}$ & $\begin{array}{c}\text { 3. roč. } \\
{[\%]}\end{array}$ & $\begin{array}{c}\mathbf{5 . ~ r o c ̌ . ~} \\
{[\%]}\end{array}$ & $\begin{array}{c}\mathbf{1 . r o c ̌ c} \\
{[\%]}\end{array}$ & $\begin{array}{c}\text { 3. roč. } \\
{[\%]}\end{array}$ & $\begin{array}{c}\text { 5. roč. } \\
{[\%]}\end{array}$ & $\begin{array}{c}\text { 1. roč. } \\
{[\%]}\end{array}$ & $\begin{array}{c}\text { 3. roč. } \\
{[\%]}\end{array}$ & $\begin{array}{c}\text { 5. roč. } \\
{[\%]}\end{array}$ \\
\hline Facebook (skupiny) & 14,9 & 21,2 & 27,3 & 28,2 & 25,2 & 27,8 & 28,6 & 20,5 & 20,0 \\
\hline primat.cz & 23,4 & 39,4 & 34,1 & 34,7 & 31,7 & 35,4 & 22,6 & 25,6 & 26,7 \\
\hline IS/Stag (el. materiály) & 10,6 & 7,6 & 4,5 & 15,3 & 11,5 & 8,9 & 11,9 & 17,9 & 5,3 \\
\hline upce.cz (intranet) & 6,4 & 3 & 2,3 & 6,5 & 5 & 3,8 & 1,2 & 2,6 & 1,3 \\
\hline LMS Moodle & 4,3 & 10,3 & 13,6 & 4,8 & 12,2 & 13,9 & 8,3 & 12,8 & 12,0 \\
\hline skripta & 10,6 & 3 & 0 & 2,4 & 1,4 & 0 & 4,8 & 0,0 & 1,3 \\
\hline přednášky & 14,9 & 3 & 4,5 & 0,8 & 1,4 & 3,8 & 0,0 & 5,1 & 8,0 \\
\hline knihovna & 6,4 & 1,5 & 0 & 0,8 & 1,4 & 1,3 & 4,8 & 5,1 & 4,0 \\
\hline spolužáci (studenti) & 8,5 & 10,6 & 13,6 & 6,5 & 10,1 & 5,1 & 11,9 & 5,1 & 16 \\
\hline
\end{tabular}

Zdroj: Vlastní zpracování

Jak je patrné z výsledků, tak zde převládají skupiny na Facebooku a primat.cz. Tyto kanály jsou primární zejména proto, že kombinují více funkcí na jednom místě. Studenti zde mohou získat př́stup ke studijním materiálům, vyměňovat si zkušenosti s ostatními studenty a mít přehled o tom, co se zrovna děje. Vše samozrrejmě probíhá online se všemi výhodami, které jsou díky moderním ICT dostupné. I přes přesun komunikačních kanálů do prostředí Internetu je fyzický kontakt se spolužáky v průběhu sledovaných let stále stabilní s podílem kolem $10 \%$. Na druhou stranu je ale v roce 2017 patrný pokles těchto kanálů. Při bližším dotazování bylo zjištěno, že důvodem je přesun komunikačních kanálů $\mathrm{k}$ mobilním aplikacím. Ty nebyly v dotazníku prímo zohledněny, resp. studenti je sice mohli uvést v kolonce další, ale až v roce 2017 se tento trend objevil ve více dotaznících. Výhodou těchto aplikací v dnešní době je, že lze skrze ně pořádat videohovory, klasické hlasové hovory či vést textové konverzace jen za cenu připojení, tedy v př́padě Wi-Fi prakticky zdarma. Zároveň byly v roce 2017 často zmiňovány i další kanály jako různá úložišstě a úschovny souborů, které nabízí různé formy sdílení souborů ve skupinách, synchronizace a verzování souborů - často jako mobilní aplikace.

Dalším zjištěním je to, že studenti se postupně odklánějí od tradičních zdrojů informací, jako jsou skripta (tištěná, ale i ta elektronická), přednášky nebo i knihovna - kde byl ale v roce 2017 
zaznamenán mírný nárůst u všech ročníků, který ale souvisí s rostoucím povědomím o existenci online knihoven a databází nabízejících přístup k některým publikacím právě skrze počítačovou sít' vysoké školy. Pokud se jedná o informační systémy, tak IS/Stag a LMS Moodle jsou stabilní, nicméně vnitřní intranet již jako zdroj informací není příliš využíván. Zde je však nutné zmínit, že studenti často samostatně uváděli studentský (školní) email, který je ale součástí intranetu. $\mathrm{V}$ tomto př́padě by se pak průměrný podíl pohyboval kolem $10 \%$. Průměr hodnot pro všechny ročníky v jednotlivých letech je zachycen na obrázku 1.

Obrázek 1: Komunikační kanály při studiu jako průměr všech ročníků ve sledovaných letech

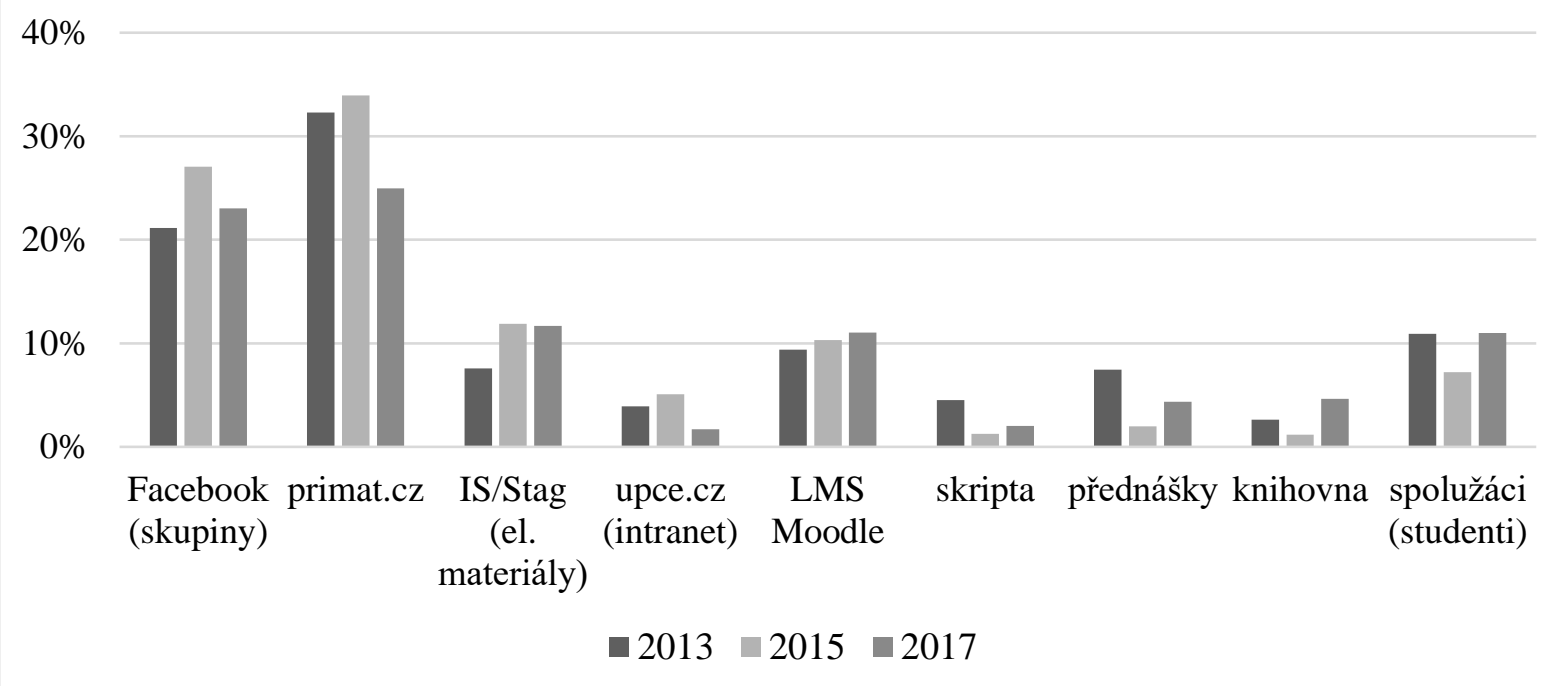

Zdroj: Vlastní zpracování

Klíčová část otázek výzkumu byla zaměřena na identifikaci vývojových trendů ve využívání komunikačních kanálů mezi studenty v průběhu jejich studia na vysoké škole. Tento vývoj byl sledován na dvou úrovních. Jednak za každý ze sledovaných roků (2013, 2015 a 2017), a pak v rámci každého roku, kde studenti měli seřadit vybrané formy elektronické komunikace podle jejich důležitosti využívání v prvním a aktuálním roce studia, když u studentů 1. ročníku šlo pouze o aktuální rok studia. Na základě pilotního průzkumu byly identifikovány tyto možnosti elektronické komunikace - Facebook jako hlavní zástupce sociálních sítí, studentské servery primat.cz a spoluzaci.cz, Moodle jako LMS dostupný na FES a emailová komunikace.

$\mathrm{Z}$ důvodu větší přehlednosti bylo nejdříve vytvořeno průměrné pořadí a jednotlivé kanály byly seřazeny: 1 . místo $=$ Facebook, 2. místo $=$ email, 3 . místo $=$ primat.cz, 4. místo $=$ LMS Moodle a 5 . místo $=$ spoluzaci.cz. Dále se pak sledoval jejich procentuální podíl pro dané místo v čase. Zde je nutné zmínit, že rozdíl mezi 3. a 4. místem byl malý a někdy si tyto kanály byly rovny nebo měly opačné pořadí. Zobrazení výstupů na následujících grafech je koncipováno tak, že porovnává první ročník studia všech dotazovaných studentů, který je zachycen jen jako obrysy, s aktuálním ročníkem studie, tzn., že 3. ročník hodnotil situaci 2 roky zpět a 5. ročník dokonce 4 roky zpět, což byl rok $2009 \mathrm{v}$ případě prvního dotazníku z roku 2013. U studentů aktuálně 1 . ročníků jsou pak obě hodnoty stejné. Změny jsou zachyceny pomocí šipek, když nahoru = růst a dolů $=$ pokles.

U studentů 5. ročníku byl v jejich prvním roce studia, tzn. v roce 2009 , nejčastěji využíán email (na prvním místě ho uvedlo $33 \%$ studentů), na druhém místě se pak umístily Facebook a primat.cz s $25 \%$ a na třetím místě pak spoluzaci.cz s $15 \%$. Během následujících let se ale 
stal hlavním kanálem Facebook, což potvrzuje výrazný nárůst na obrázku 2. Další komunikační kanály také zaznamenaly nárůst, protože se přesunuly na další místa v pořadí. Tuto dobu tak lze charakterizovat jako dominanci sociální sítě Facebook, který nahradil existující komunitní portály jako spoluzaci.cz a primat.cz. V roce 2015 se tyto portály dále propadaly nebo alespoň stagnovaly, co se využívání týká, viz obrázek 3. Zároveň došlo ke korekci růstu Facebooku, když ten vykázal tentokrát pokles o přibližně $5-10 \%$ při přiřazení na prvním místě. U studentů 5. ročníku je ještě patrný růst, ale ten je dán porovnáním výsledků za jejich 1. ročník studia, tzn. rok 2011.

Obrázek 2: Porovnání vývoje využívání komunikačních kanálů v prvním a aktuálním ročníku studia studentů v roce 2013 podle \% místa prriřazení

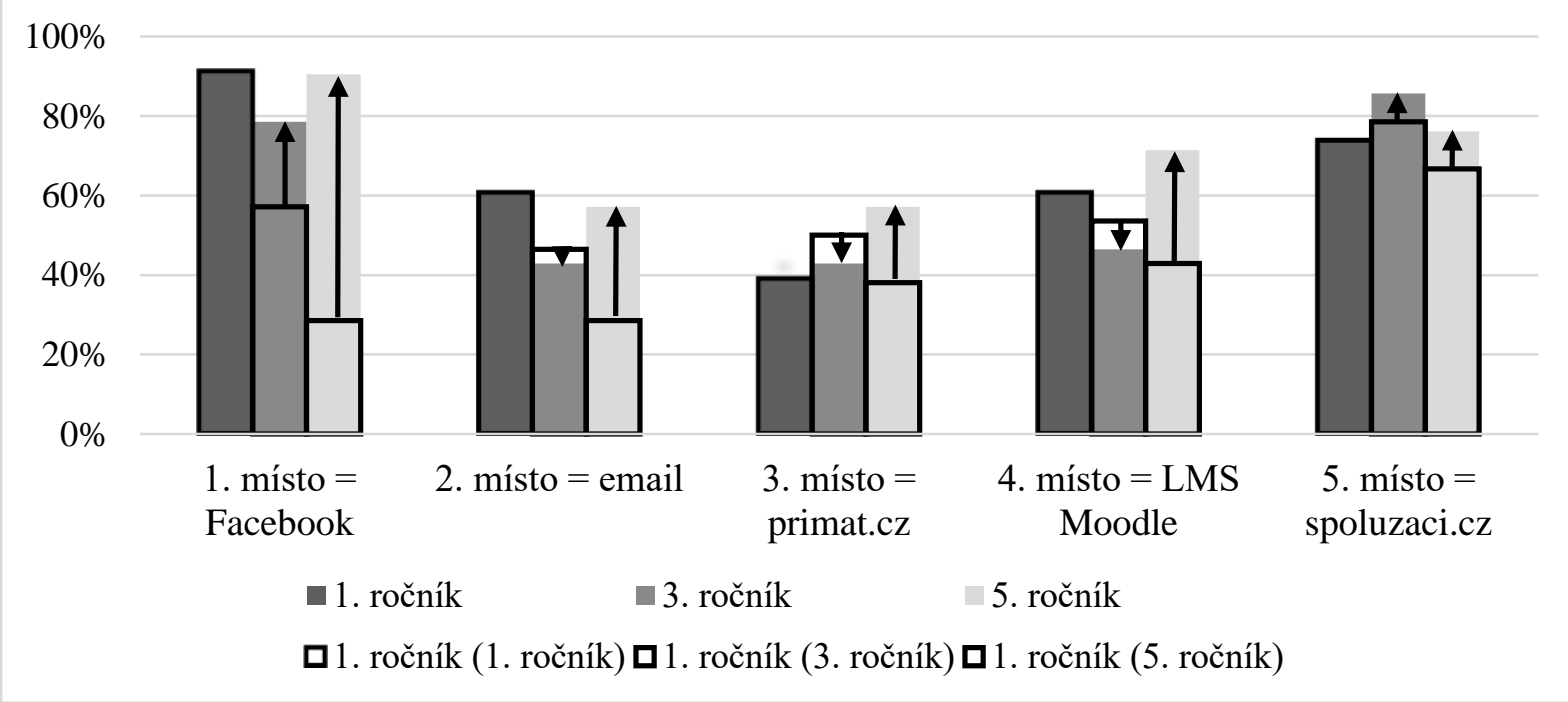

Zdroj: Vlastní zpracování

Obrázek 3: Porovnání vývoje využívání komunikačních kanálů v prvním a aktuálním ročníku studia studentů v roce 2015 podle \% místa pririrazení

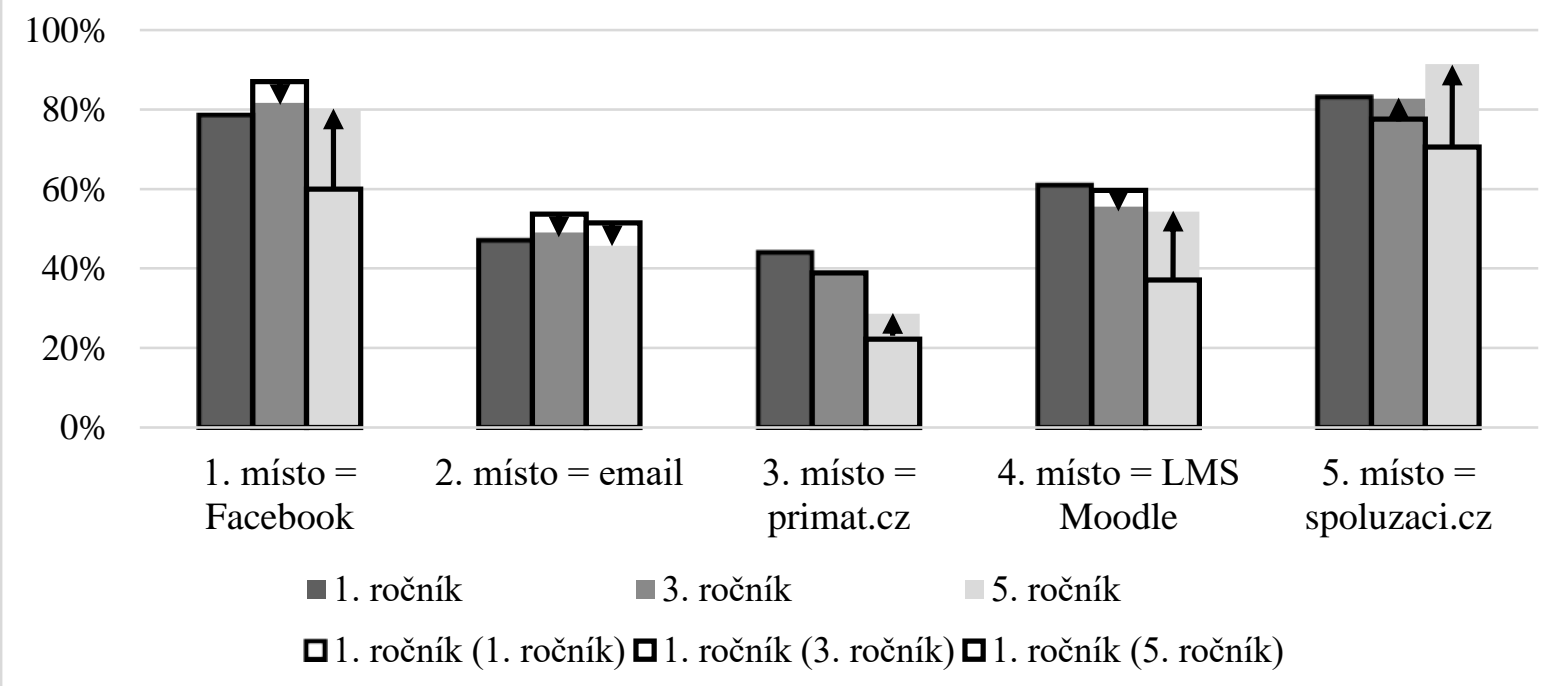

Zdroj: Vlastní zpracování 
Pro rok 2015 se již v odpovědích objevují i další možnosti komunikace, především využívání chytrých mobilních telefonů a souvisejících aplikací. Tyto možnosti proto snižují procentuální přiřazení podle pořadí. V roce 2017 Facebook stagnuje nebo mírně klesá, když postupný nárůst zaznamenává emailová komunikace, což je zapříčiněno rostoucí nabídkou služeb souvisejících s emailovými účty. Na první místo tak v roce 2017 přiřadilo email asi $10 \%$ studentů. Význam komunitních portálů v tomto roce dále klesá. LMS Moodle v průběhu sledovaných let stagnuje, což je ale způsobeno tím, že ho studenti sice chápou jako součást studia, ale více ho nepoužívají. Vše je zachyceno na obrázku 4.

Obrázek 4: Porovnání vývoje využívání komunikačních kanálů v prvním a aktuálním ročníku studia studentů $v$ roce 2017 podle $\%$ místa přiřazení

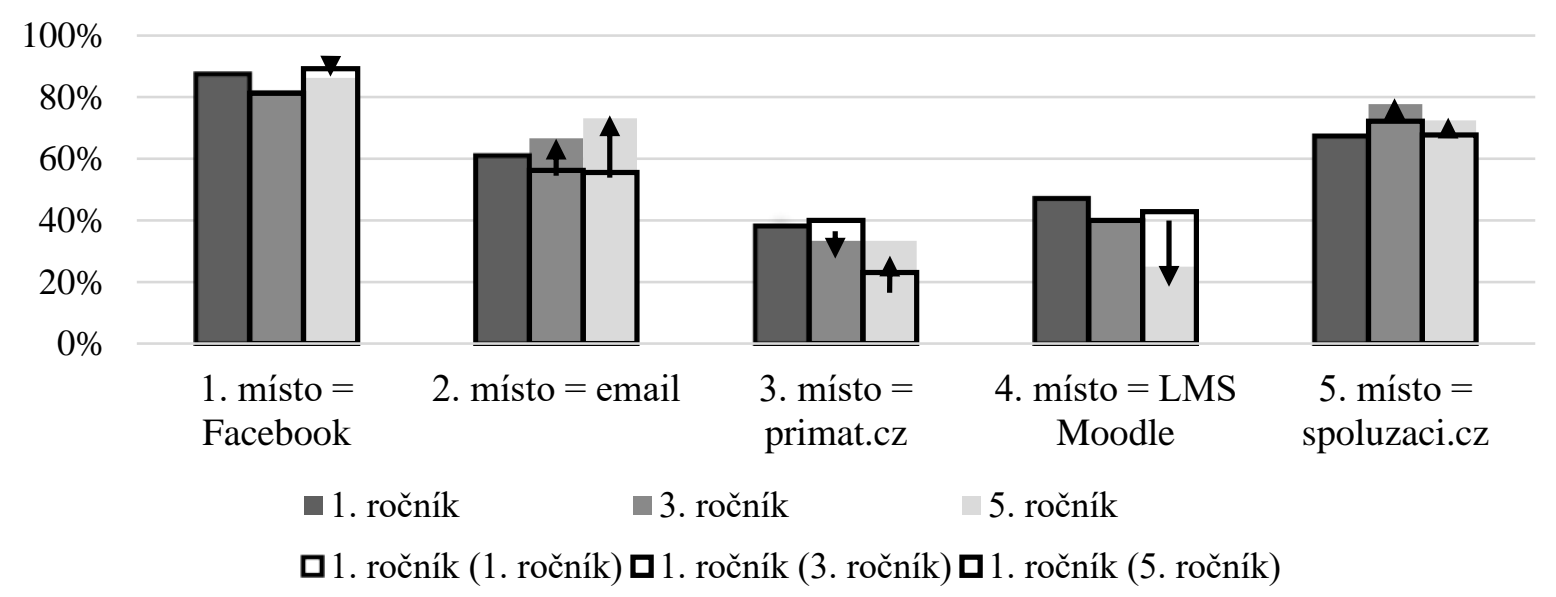

Zdroj: Vlastní zpracování

Další část výzkumu se tak věnovala systémům pro řízení výuky, které jsou zpravidla centrálním bodem vzdělávacího procesu. I přesto, že dnes tyto systémy nabízí širokou škálu funkcí, tak jsou často využívány jen jako úložiště studijních materiálů, př́ípadně jako místo pro nahrávání průběžných úkolů nebo závěrečných projekti̊ a prací. Jelikož na FES již dlouhodobě funguje LMS Moodle, tak byli studenti v rámci výzkumu dotázáni na činnosti, ke kterým tento systém využívají. Výsledky jsou zachyceny v následující tabulce 3 . Žádný ze studentů ve sledovaných letech neuvedl, že systém používá ke komunikaci s ostatními studenty a hlavní zdroj informací pro studium. Většina studentů tak systém používá pouze pro plnění povinných úkolů. Pouze studenti 3. ročníku častěji využívají i volitelných materiálů. Tady lze předpokládat, že to souvisí s koncem jejich bakalářského studia, kdy se připravují i ze zde dostupných materiálů. Nicméně $\mathrm{k}$ určení přesného důvodu by bylo nutné provést další výzkum.

Tabulka 3: Způsoby využívání LMS Moodle a vývoj jejich procentuálního podílu v čase

\begin{tabular}{|c|c|c|c|c|c|c|}
\hline & $\mathbf{2 0 1 3}[\%]$ & $\mathbf{2 0 1 5}[\%]$ & $\mathbf{2 0 1 7}[\%]$ & M [\%] & SD \\
\hline \multicolumn{2}{|c|}{ Pouze studium (vše co kurz nabízí i rozšiřující volitelné materiály, diskuze a zpětnou vazbu). } \\
\hline 1. ročník & 35 & 29 & 8 & 24,0 & 4,9 \\
\hline 3. ročník & 46 & 45 & 44 & 45,2 & 7,5 \\
\hline 5. ročník & 33 & 43 & 21 & 32,5 & 4,0 \\
\hline Pouze studium (jen povinné úkoly). & 65 & 71 & 92 & 76,0 & 9,9 \\
\hline 1. ročník & 54 & 55 & 56 & 54,8 & 8,8 \\
\hline 3. ročník & 67 & 57 & 79 & 67,5 & 3,4 \\
\hline
\end{tabular}

Zdroj: Vlastní zpracování 
V průběhu sledovaných let je již patrný růst nezájmu o rozšiřující volitelné materiály, možnosti diskuze a zpětnou vazbu realizovanou v prostředí LMS Moodle. Z těchto výsledků lze proto usuzovat, že studentům tento způsob komunikace a výměny informací již nevyhojuje. Chybí jim moderní funkce, jako jsou synchronizace obsahu a př́stup z různých zařízení, verzování odevzdávaných úkolů a jejich efektivnější správa pro pozdější využívání, a především celkově větší nabídka funkcí pro sdílení studijních materiálů - zpravidla těch, které si studenti vytvářejí sami, a pak mezi sebou sdílí např. v rámci práce na společných semestrálních projektech.

V otázce zaměřené na získání podrobnějších informací o využívání různých komunikačních kanálů dostupných v LMS Moodle je vývoj následující. Studenti mohli vybrat i více odpovědí. Nejčastěji studenti využívají sekci s novinkami, když všichni mají nastaveno odebírání novinek emailem. Tato sekce je úzce propojena s emailovou komunikací, když slouží jako upozornění na novou informaci, která je vložena v novinkách. Po poklesu pro rok 2015 je využívání této sekce stabilní. Diskuzní fórum si drží stabilní podíl pod 20 \%. Soukromé zprávy (chat) jsou pak využívány minimálně. U studentů z 1 . ročníku je ještě patrná neznalost nabídky jednotlivých funkcí LMS Moodle, která se pohybuje v průměru kolem $20 \%$ a je přibližně 4 krát vy̌šsí než u studentů 3. ročníku. Změny mezi jednotlivými roky jsou v tabulce 4.

Tabulka 4: Změna ve využívání jednotlivých možností komunikace v LMS Moodle během sledovaných let

\begin{tabular}{|c|c|c|c|c|c|c|}
\hline \multirow{2}{*}{$\begin{array}{l}\text { Změna mezi roky / } \\
\text { komunikační kanál }\end{array}$} & \multicolumn{3}{|c|}{$2013-2015$} & \multicolumn{3}{|c|}{$2015-2017$} \\
\hline & $\begin{array}{l}\text { 1. ročník } \\
{[\%]}\end{array}$ & $\begin{array}{l}\text { 3. ročník } \\
{[\%]} \\
\end{array}$ & $\begin{array}{c}\text { 5. ročník } \\
{[\%]} \\
\end{array}$ & $\begin{array}{l}\text { 1. ročník } \\
{[\%]}\end{array}$ & $\begin{array}{c}\text { 3. ročník } \\
{[\%]} \\
\end{array}$ & $\begin{array}{c}\text { 5. ročník } \\
{[\%]} \\
\end{array}$ \\
\hline Novinky & $-13,2$ & $-15,1$ & $-16,3$ & 1,7 & 3,6 & $-3,7$ \\
\hline Diskuzní fórum & $-1,8$ & 1,9 & 5,4 & $-4,0$ & $-8,7$ & 1,8 \\
\hline Soukromé zprávy (chat) & 1,6 & 3,8 & 2,1 & 0,8 & $-11,0$ & $-2,1$ \\
\hline $\begin{array}{c}\text { Žádnou funkci v Moodle } \\
\text { nevyužívám }\end{array}$ & 23,6 & 13,7 & 16,7 & 16,5 & 20,4 & $-2,9$ \\
\hline $\begin{array}{l}\text { Vůbec nevím o existenci těchto } \\
\text { služeb }\end{array}$ & $-10,2$ & $-4,4$ & $-7,9$ & $-15,1$ & $-4,3$ & 7,0 \\
\hline
\end{tabular}

Zdroj: Vlastní zpracování

Roste naopak podíl těch, kteří v LMS Moodle žádnou z těchto funkcí nevyužívají, a to i přesto, že podíl studentů, kteří o existenci těchto funkcí vůbec neví, klesá. Z toho je tedy patrné, že se stále nedaří přesvědčit a zaujmout studenty natolik, že tyto systémy nabízí komplexní podporu studijního procesu, kde vše mají na jednom místě. Tento vývoj je nejvíce patrný na průměrných hodnotách pro všechny ročníky ve sledovaných letech, což je zachyceno na obrázku 5. 
Obrázek 5: Komunikace v LMS Moodle jako průměr všech ročníků ve sledovaných letech

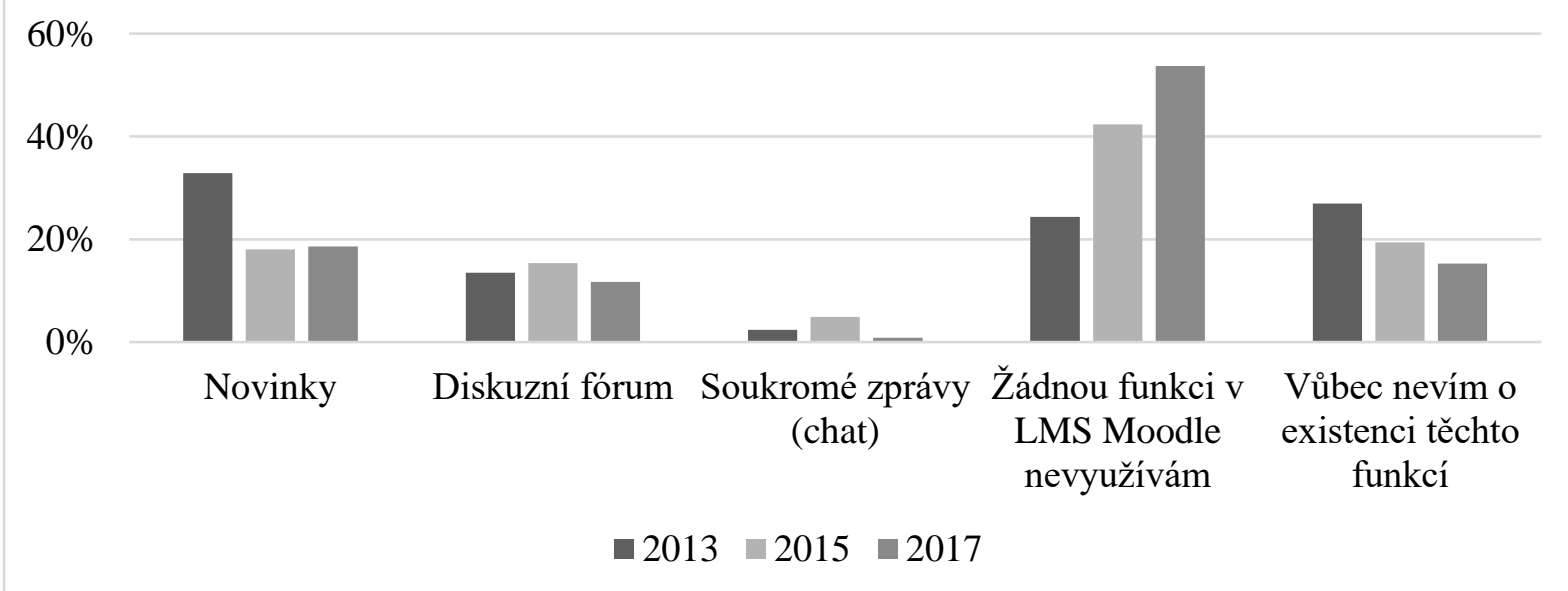

Zdroj: Vlastní zpracování

Na základě předchozích výsledků je tedy patrný vývoj směrem k integraci souvisejících služeb, proto další $\mathrm{z}$ otázek zjišt'ovala názor studentů na možnost propojení LMS Moodle s účty na Google nebo Facebook, resp. přihlášení do Moodle přes tyto účty. Výsledky jsou pak zachyceny na následujícím obrázku 6 . Průměrné výsledky ukazují, že studenti mají o tuto možnost zájem, nicméně jejich podíl $\mathrm{v}$ jednotlivých letech klesá, stejně jako podíl s ohledem na ročník studia. Studenti vyšších ročníků tedy k této otázce přistupují spíše konzervativně, a to s ohledem na bezpečnost a ochranu soukromí. Mezi odpověd'mi se objevilo např. ,provázanost a registrace má za di̊sledek, že to visí na zdi“, ,propojeni mi narušuje oddělení školy a soukromého života“ apod. Systém Moodle sice nabízí možnost přidat přihlášení přes účty Google, Facebook nebo Windows Live, ale vysoké školy většinou z důvodu různých procesních, administrativních nebo technických překážek souvisejících s bezpečností nestíhají držet tempo v aktualizacích tohoto open source LMS.

Obrázek 6: Kladné odpovědi na propojení různých účtů s LMS Moodle podle ročníků studia

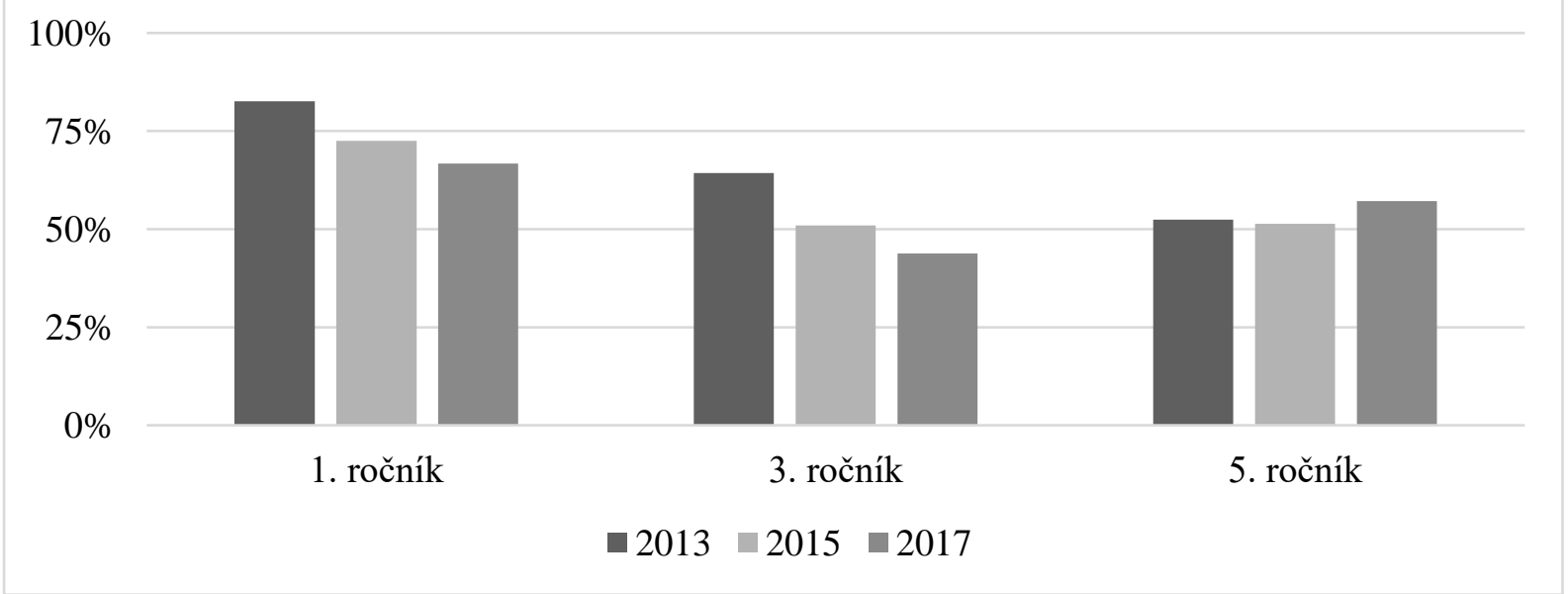

Zdroj: Vlastní zpracování

\section{Vyhodnocení výzkumných hypotéz a jejich omezení}

Testování hypotézy je proces, jehož cílem je rozhodnutí, zda na základě získaných informací lze přijmout nebo zamítnout vztah mezi sledovanými jevy u př́slušného sledovaného souboru. 
Vyhodnocení tedy probíhalo podle pokynů popsaných v Creswell (2012), když tato publikace se zaměřuje přímo na výzkum související se vzděláváním.

S ohledem na výše popsané výsledky lze vyhodnotit splnění definovaných hypotéz. Pro potřeby ověrení hypotézy H1 byly odpovědi rozděleny do dvou kategorií: online a klasické kanály, kde první kategorii tvoří: Facebook (skupiny), primat.cz, IS/Stag (el. materiály), upce.cz (intranet) a LMS Moodle, a druhou kategorii tvoří: skripta, přednášky, knihovna a spolužáci (studenti). Pro otestování vztahu byl tak použit Chí-kvadrát test nezávislosti, který se použivá k posouzení závislosti dvou veličin měřených na prvcích téhož výběru, když zároveň získaná statistická data nepochází z opakovaných měření na témže statistickém souboru. První hypotéza H1 byla na dotazovaném vzorku studentů na hladině významnosti 0,05 potvrzena pro každý z roků, i když byl v roce 2017 u hlavních elektronických komunikačních kanálů zaznamenán mírný pokles. Nicméně i přesto tato forma komunikace převažuje. Jak bylo zmíněno již výše i tradiční formy komunikace a získávání informací postupně přecházejí do online prostředí. At' už se jedná o elektronické informační zdroje knihoven nebo o online streaming přednášek, kdy již studenti nemusí být fyzicky př́tomni na přednáškách.

Tento trend vytváření online ekosystému studijního procesu ale má i své nevýhody. Jak již bylo zmíněno výše, tak v rámci komunikačních kanálů dochází k různé úrovni šumu a bez dostatečné zpětné vazby nelze zajistit adekvátní kvalitu tohoto procesu. Moderní ICT a online metody tak často nejsou dostatečně využívány v šírii, kterou nabízejí. Často zde lze nalézt různá restriktivní omezení, jako např. přístup k některým službám jen z počítačové sítě vysoké školy, kdy adresy IP mimo tuto sít' jsou blokovány. Nicméně v tomto kontextu je nutné uvažovat problematiku bezpečnosti, která dostupnost některých těchto kanálů pro studenty neumožňuje.

Hypotéza H2 je také potvrzena, když v prvních sledovaných letech je tento trend jednoznačný a $\mathrm{v}$ posledním realizovaném dotazování je tento trend potvrzen s počínajícím přesunem směrem ke službám propojeným s emailovými účty. Hypotéza H3 byla testována pro jednotlivé roky a zároveň pro průměrné hodnoty za všechny sledované roky. Za tímto účelem byla aplikována vícefaktorová ANOVA, když $\mathrm{p}<0,05$ bylo považováno jako statisticky signifikantní. Faktory byly zvoleny hodnoty pořadí pro 1 . místo $=$ Facebook, 2 . místo $=$ email, 3 . místo $=$ primat.cz, 4. místo $=$ LMS Moodle a 5. místo = spoluzaci.cz. $H_{0}$ tak testovala, že daná pořadí pro všechny sledované ročníky mají stejnou střední hodnotu. $\mathrm{H}_{1}$ pak testovala, že tyto hodnoty se liší. Pro rok 2013, rok 2015 i rok 2017 byla hypotéza $\mathrm{H}_{0}$ zamítnuta na zvolené hladině významnosti. Pro průměr všech roků již však na hladině významnosti 0,05 hypotézu $\mathrm{H}_{0}$ zamítnout nelze. Nicméně proto, že jsou tato data již průměr z průměrů různých pozorování, tak jejich vypovídací hodnota je snížená. Hypotéza H3 je tedy potvrzená a lze konstatovat, že preferované kanály studentů nižších ročníků se liší od těch, které používají studenti vy̌šsích ročníků.

Poslední hypotéza H4 byla rovněž potvrzena, opět s pomocí Chí-kvadrát testu nezávislosti, když počet kladných odpovědí ve sledovaných letech i přes jejich klesající počet přesahuje 50 \%. Lze tak tvrdit, že studenti by uvítali vyšší míru integrace kurzů v LMS Moodle se sociálními sítěmi nebo dalšími službami jako je Google nebo Windows Live. Tento přístup by tak mohl zvrátit přetrvávající trend, kdy je patrný růst nezájmu o rozšiřující volitelné materiály, diskuze a zpětnou vazbu realizovanou $\mathrm{v}$ tomto prostředí. I přes širokou nabídku rozšiřujících modulů na oficiálních stránkách LMS Moodle a také existující publikační výstupy jako např̀. Al-Kindi a Al-Suqri (2017), Caminero et al. (2012) a Daraghmi et al. (2014) jsou tyto možnosti v praxi využívány pouze minimálně. Související důvody by pak měly být zkoumány v samostatném výzkumu, protože zájem o tato rozšíření mezi studenty je. 
Prvním omezením výsledků tohoto výzkumu může být, že jde o omezený vzorek bez nároku na reprezentativnost, tzn. rovnoměrné rozložení studentů jednotlivých ročníků či oborů studia. Jelikož však bylo během trvání výzkumu získáno velké množství dat, a také vzhledem k tomu, že data byla validována pomocí statistických metod, se tento vzorek jeví jako dostačující pro vyvozování závěrů. Dalším omezením interpretace výsledků tohoto výzkumu je možný vliv subjektivního posuzování hodnotitele. $Z$ tohoto důvodu bylo vyhodnocení provedeno nezávisle všemi autory. Posledním omezením, které by mohlo ovlivnit aplikovatelnost výsledků v praxi je to, že každá instituce má své vlastní předpisy, které vycházejí z existujícího mixu ICT a také systémů používaných pro podporu studijního procesu. S ohledem na to, že některé tyto systémy jsou v určité fázi studia povinné a každý se s nimi tak musí do nějaké míry naučit interagovat, je možné, že tyto zkušenosti mohou studenty ovlivnit s ohledem na volbu daného kanálu.

\section{Diskuze a komparace s již realizovanými výzkumy}

$\mathrm{V}$ minulých letech již bylo provedeno několik výzkumů, které se zabývaly rolí a využíváním různých komunikačních kanálů pro podporu vzdělávacího procesu. Autoři Klement a Dostál (2012) realizovali případovou studii reflektující rozvoj e-learningu ve vysokoškolské praxi. Ta byla dokumentována na př́íladu Pedagogické fakulty Univerzity Palackého v Olomouci. Jako hlavní trendy zde byly identifikovány principy interaktivity, jakožto předpokladu pro efektivní učení studentů a jako prostředku pro dosahování většího spektra učebních cílů, a multimediality reprezentující nutnost zajištění přenosu učiva ke studentovi co nejvíce různými kanály, které budou přenášet informaci stejného obsahu a stimulovat více prvků studentova vnímání. Další výzkum těchto autorů řešil, zda jednotlivé prvky elektronických výukových materiálů pro elearning jsou stejně potřebné pro různé skupiny studentů při respektování jejich individuality. $\mathrm{K}$ tomu by mělo pomoci to, aby materiály obsahovaly prvky pro zajištění navigace ve studiu, multimediality obsahu, interaktivity ve vzdělávání, a zprostředkování obsahu různými kanály (Klement a Dostál 2014).

Poulová et al. (2010) pak ve své práci řešily určení předpokladů pro zavedení e-learningu do vysokoškolského vzdělávání, když porovnání bylo realizováno na př́kladu Fakulty informatiky a managementu Univerzity Hradec Králové. Autorky zde pak zdůrazňují individualizaci studia prostřednictvím výuky s podporou ICT, která poskytuje nejen možnost volby času a místa ke studiu, ale i studijního tempa a př́stupu ke studentovi. Další informace lze nalézt také v Liška a Česal (2008), kde autoři provedli výzkum zaměřený na postoje studentů vysokých škol k elearningu. Cílem bylo získat názory na výuku v elektronickém prostředí, zejména u studentů prezenční formy studia. Autoři zde zdůrazňují, že je nutné volit vhodnou vzdělávací strategii, která odráží možnosti využití specifického kanálu souvisejícího se vzdělávacím obsahem.

Na základě výše popsaných zjištění lze konstatovat, že problematika zefektivňování a trvalého zlepšování kvality vzdělávacího procesu s využitím ICT je v centru pozornosti různých autorů. Nicméně otázka toho, jak zajistit hlubší interakci studentů s výukovým obsahem je i nadále tématem diskuzí. V kontextu výsledků prezentovaných $\mathrm{v}$ tomto př́spěvku lze souhlasit $\mathrm{s}$ tím, že je nutné zajistit jednak možnost individuálního výběru, a jednak využívat prvky interaktivity a multimediality, které budou mít vliv na výběr relevantních komunikačních kanálů studenty.

\section{Doporučení pro praxi a další výzkum}

Realizovaný výzkum přinesl empirická zjištění, reagoval na definované hypotézy a ukázal, zda vzájemný vztah a jeho vývoj mezi sledovanými ukazateli jsou či nejsou statisticky významné. Následující doporučení vyplývající ze závěrů longitudinálního výzkumu by měla být chápána v kontextu identifikace trendů využívání komunikačních kanálů v průběhu studia studenta na vysoké škole. Tyto trendy by měly být reflektovány při tvorbě a zejména správě komunikačních 
kanálů a výměně informací jak mezi studenty, tak především mezi studenty a vyučujícími. Tím by se měl odstranit prostor pro neurčitost v komunikaci, neúplné informování, vznik účelových informací, zatajování informací a další nejasnosti, které mohou narušit vzdělávací proces.

- Komunikační kanály by se měly různě kombinovat s ohledem na obsah, význam a cíl komunikačního procesu, tzn. stanovit důležitost kanálů a studenty s tím seznámit, což zabrání např. tomu, že student v množství zpráv přehlédne tu důležitou.

- Více využívat Facebook jako komunikačním kanál s nejširší uživatelskou základnou, např. přes vytváření a řízení diskuzních skupin, kam lze přeposílat zprávy z LMS nebo dalších systémů.

- Obecně podporovat propojování s externími účty, především Google, protože studenti v dnešní době vyžadují i další služby, které jsou spojené např. s narůstající velikostí digitálních studijních materiálů, které je nutné někde ukládat a zároveň efektivně sdílet.

- Lze doporučit větší důraz na školení v užívání ICT a univerzitních systémů používaných při studiu, zejména jejich propojení s již studenty používanými kanály, např. přeposílání emailů.

- LMS Moodle je málo využívaný jednak z důvodu malé aktivní uživatelské základny, a jednak také proto, že je tento systém pro studenty málo atraktivní, což upozorňuje na problém rigidity při migraci a aktualizaci různých verzí systémů ve vysokoškolském prostředí.

- Více sledovat trendy vývoje a poučit se z toho, že studentské portály typu spoluzaci.cz či primat.cz prrišly o své uživatele také díky tomu, že nedokázaly dostatečně rychle reagovat na nastalé trendy, nebo odradily některé uživatele změnami v nových funkcích a designu těchto portálů.

- Větší práce s mobilními aplikacemi, zejména pokud jde o responzivní design, když již existují mobilní aplikace pro LMS, jako např. Moodle Mobile, ale administrátoři těchto systémů s nimi nepracují a tyto funkce pro studenty u jednotlivých stránek nepovolují.

- Pro rozvoj komunikačních kanálů je dnes tedy také zásadní jejich dostupnost přes chytré mobilní telefony, kde jsou často využívány služby jako např. Skype nebo Messenger.

Jelikož tento výzkum pracoval se studenty prezenčního studia, další výzkum by měl směřovat do oblasti komunikačních kanálů využívaných studenty v kombinované formě studia, u kterých je právě fyzický kontakt s ostatními studenty a vyučujícími omezen na několik setkání během semestru, a zároveň volba komunikačních kanálů je důležitým faktorem úspěšného studia. Zde by měl být kladen důraz zejména na vnímání a zkušenosti s ICT a systémy pro podporu studia.

\section{Závěr}

Tento př́spěvek prezentuje výsledky výzkumu zaměřeného na komunikační kanály v průběhu studia a jejich vývojové trendy. Jelikož byly zachyceny názory významného vzorku studentů mezi roky 2013 a 2017, lze formulovat tyto závěry potvrzené ověřením definovaných hypotéz. Online komunikační kanály převažují, ale jejich podíl vưči tradičním kanálům podle posledního dotazování z roku 2017 již stagnuje či mírně klesá. Nejrozšířenější jsou stále sociální sítě, zejména Facebook, a zde vytvářené skupiny. Komunitní portály jako spoluzaci.cz a primat.cz jsou dnes již v útlumu, protože nabídka jejich funkcí často neodpovídá současným požadavkům studentů na výměnu informací.

Do popředí se tak dostaly jednak služby nabízející komplexní funkcionality jak pro komunikaci, tak pro sdílení a výměnu dat a informací, a jednak také mobilní aplikace, které splňují současné požadavky na dostupnost a rychlost komunikace. Tyto trendy však nejsou ve studijním procesu často reflektovány, a proto je nutné iniciovat diskuzi $\mathrm{k}$ této problematice. $\mathrm{Z}$ tohoto důvodu byla představena sada doporučení, které by měly vzít do úvahu jak administrátoři těchto systémů, 
tak vyučující a tvůrci kurzů. Zejména pro oblast propojení LMS a využívání mobilních aplikací se nabízí velké množství možností, které umožní zrychlení a zároveň také zkvalitnění nejenom těchto komunikačních kanálů, ale zároveň celého vzdělávacího procesu.

Výsledky tohoto výzkumu pak jasně naznačují, že za účelem udržení si stávajících a získáním nových uživatelů, je zásadní zjišt'ovat od těchto uživatelů zpětnou vazbu a také jejich názory, protože jinak dané komunikační médium ztratí svůj význam, resp. pozici na trhu.

\section{Literatura}

[1] AL-KINDI, S. S. and M. N. AL-SUQRI, 2017. Mobilizing Learning: Using Moodle and Online Tools via Smartphones. International Journal of Knowledge Content Development \& Technology, 7(3), 67-86. ISSN 2234-0068.

[2] ARKORFUL, V. and N. ABAIDOO, 2015. The role of e-learning, advantages and disadvantages of its adoption in higher education. International Journal of Instructional Technology and Distance Learning, 12(1), 29-42. ISSN 1550-6908.

[3] CAMINERO, A. C. et al., 2012. Work in progress: Extending a LMS with social capabilities: Integrating Moodle into Facebook. In: 2012 Frontiers in Education Conference Proceedings. Washington, DC: IEEE, s. 1-2. ISBN 978-1-4673-1351-3.

[4] CRESWELL, J. W., 2012. Educational Research: Planning, Conducting, and Evaluating Quantitative and Qualitative Research. Upper Saddle River, NJ: Pearson Publishing. ISBN 978-0-13-136739-5.

[5] DARAGHMI, E. Y., C. H. HSIAO and S. M. YUAN, 2014. A New Cloud Storage Support and Facebook Enabled Moodle Module. In: 7th International Conference on UbiMedia Computing and Workshops. Washington, DC: IEEE, s. 78-83. ISBN 978-1-4799-4266-4.

[6] DEVITO, J. A., 2008. Základy mezilidské komunikace. Praha: Grada Publishing. ISBN 978-80-247-2018-0.

[7] KLEMENT, M. a J. DOSTÁL, 2012. Využívání a role e-learningu v současném vysokoškolském vzdělávání. Aula, 20(1), 93-110. ISSN 1210-6658.

[8] KLEMENT, M. a J. DOSTÁL, 2014. Styly učení dle klasifikace vark a možnosti jejich využití ve vysokoškolském vzdělávání realizovaném formou e-learningu. JTIE, 6(2), 5867. ISSN 1803-537X.

[9] LIŠKA, V. a J. ČESAL, 2008. Postoje studenti̊ vysokých škol ke-learningu. Praha: Fakulta stavební ČVUT v Praze. ISBN 978-80-01-04214-4.

[10] LNĚNIČKA, M. a R. MÁCHOVÁ, 2013. Využívání komunikačních médií v systému Moodle v průběhu studia. In: Média a vzdělávání 2013 - Sborník recenzovaných príspěvků mezinárodni védecké konference. Praha: Extrasystem Praha, s. 38-41. ISBN 978-8087570-15-9.

[11] MÁCHOVÁ, R. a M. LNĚNIČKA, 2015. Vývoj využívání komunikačních médií studenty v průběhu jejich studia na vysoké škole. Media4u Magazine, 12(2), 20-25. ISSN 12149187.

[12] POULOVÁ, P., M. SOKOLOVÁ a I. ŠIMONOVÁ, 2010. Předpoklady zavedení elearningu do vysokoškolského vzdělávání a hodnocení jeho přínosu v procesu formování a rozvoje kompetencí studentů. Aula, 18(3), 20-27. ISSN 1210-6658. 